\title{
National Professor A.K.M. Nurul Islam
}

(27 October 1928 - 1 July 2006)

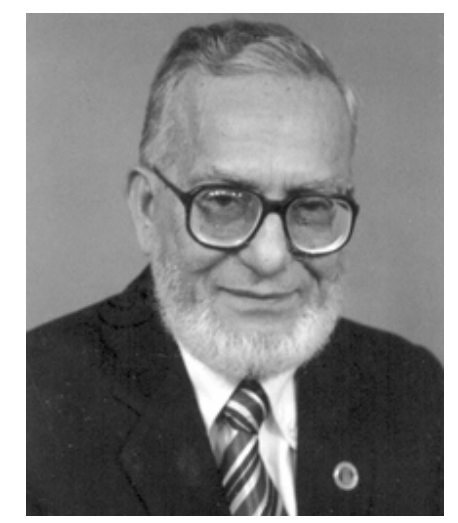

Dr. A.K.M. Nurul Islam, the National Professor, Department of Botany, University of Dhaka passed away on 1 July 2006 at the age of 78 at a private hospital in Dhaka. He was receiving treatment for recently diagnosed cardiovascular problems. With his departure Bangladesh has not only lost the pioneer in the fields of Phycology and Limnology, but also an outstanding scholar of Botany.

Dr. Nurul Islam started his career as an academic by joining the University of Dhaka as a Lecturer of the then Department of Biology in 1952 after completing his MSc in the same department in 1951. In 1960, he received his $\mathrm{PhD}$ degree from the Michigan State University, USA where he revised the filamentous green algal genus Stigeoclonium under the supervision of Prof. G.W. Prescott. He continued his affiliation with the Department of Botany, University of Dhaka for about 54 years as a Professor (retiring in 1990), Supernumerary Professor (1990-2000) and Honorary Professor (2001-January 2006). Dr. Nurul Islam's relationship with his favorite Department reached a new level in February 2006 when he became a National Professor and remained in that position until his death. It was an excellent tribute from the Government of Bangladesh to his life-long devotion and enthusiasm in teaching and research. Prof. Nurul Islam was also the Founder Dean of the Faculty of Biological Sciences, University of Dhaka in 1975 and served the Department of Botany as its Head and Chairman on several occasions (1964-1975).

Prof. Nurul Islam, popularly known as 'DNI Sir' (Dr. Nurul Islam Sir) among his students, was a superb combination of academic and scientist - an excellent example for the aspiring academics. He and his coworkers published 195 original research articles in reputed national and international journals including the latest one published in this current issue of Bangladesh Journal of Plant Taxonomy. He described the algal genus Kirchneriellosaccus Islam along with about 300 new algal species and varieties, many of 
which have been included in the world monographs. Over the past five decades he guided about 40 students for MSc and a few for PhD degrees in the fields of Phycology, Limnology, Hydrobiology and Marine Biology. Many of his students are now wellestablished at home and abroad in academic and other professional arenas. Prof. Nurul Islam is regarded as the 'Father of Phycology and Limnology' in Bangladesh for his extraordinary leadership and contributions in these fields.

As a recognition of his contributions to the development of science, Prof. Nurul Islam was elected a Fellow of the Bangladesh Academy of Sciences (1980), Bangladesh Botanical Society (1997) and Asiatic Society of Bangladesh (2003). For his overall original contributions to plant sciences, the highest awards were bestowed upon Dr. Nurul Islam by the Bangladesh Academy of Sciences (1993), Dhaka University Alumni Association (1996) and Bangladesh Botanical Society (2003).

Prof. Nurul Islam was one of the founding members of Bangladesh Association of Plant Taxonomists. He was elected as the President of this Association and the Chief Editor of its research journal Bangladesh Journal of Plant Taxonomy in 2002 after the death of the founding President and Chief Editor Prof. M. Salar Khan and remained in the office until his death. He was very earnest in performing his responsibility in achieving the purpose of the Association and in publishing its Journal despite many constraints.

During his association with other learned societies, Dr. Nurul Islam was also elected as the President of Bangladesh Botanical Society (1985-1986) and Asiatic Society of Bangladesh (1992-1993). He also efficiently edited the Journal of the Asiatic Society of Bangladesh, Science; Dhaka University Studies, Part B (Sci.) and Part E (Sci.); Bangladesh Journal of Botany; Journal of Scientific Research (BAAS Journal) etc. for several years between 1973 and 1990. He showed his brilliance in editing books as well. He edited an excellent compilation entitled "Two Centuries of Plant Studies in Bangladesh and Adjacent Regions" (Asiatic Society of Bangladesh, 1991) and was one of the editors of the 5 volumes of "Bangla Academy Science Encyclopedia" (in Bangla) (Bangla Academy, 1998-2005). The other involvements of Prof. Nurul Islam include, the preparation of the District Gazetteers between 1963 and 1980, contributing to Government review committees and acting as a $\mathrm{PhD}$ thesis examiner for the universities of New Zealand, India and Bangladesh. Over the last couple of years of his life he had been deeply engaged in preparing "Encyclopedia of Flora and Fauna of Bangladesh" to be published by Asiatic Society of Bangladesh. Given his vast knowledge on the subject, the preparation of chapters on algal flora, especially desmids, will greatly be hampered in his absence.

Prof. Nurul Islam was a very good speaker. Besides Botany and Biology in general, he had good understanding of many different subjects ranging from Geology to Sociology, and especially the religion. As a man of principles and with strong personality, Dr. Nurul Islam never paused in exerting his strong opinions on issues came 
before him in his professional life. On the other hand, his sense of humor was wonderful - poised but still made him accessible even to the first year undergraduate students. Nevertheless, there were a few aspects of his life which were missed out by many of his students and colleagues: poetry-writing, passion for gardening and playing of musical instruments.

Prof. Nurul Islam was the first professor I met on my first day as a graduate student of Botany in 1992. I became associated with him in 1996 as his MSc thesis student and the affiliation got stronger every year until he passed away. I often wonder how he guided me through my metamorphosis, from a naive student to a professional, over these years and how he sculpted our relationship accordingly, which was always a combination of mentoring, love and respect. I will indeed miss his advice on my research, editing, reviewing and personal life; working with him in his small office; and especially, his bringing of extra lunch for me.

Despite the opportunities to work and settle abroad, Prof. Nurul Islam preferred to teach and conduct research works in Bangladesh. He found it very sad that promising workers in Botany complaining about the scarcity of resources. But Dr. Nurul Islam had shown throughout his life that constraints like paucity of resources could be overcome by vision, enthusiasm and sense of responsibility to the area of interest and above all to the nation. His philosophy reminds me a quote from Goethe's work "It does not matter what the cage is like but whether the bird can sing."

Prof. Nurul Islam will always be remembered for his sincerity, dedication, hard-work and patience in doing research. But in the latter years, he was very concerned about the alarming reduction of original work done by Bangladeshi academics and scientists in the field of Taxonomy, and Plant Science in general. His uncompromising attitude towards the quality of work sometimes portrayed him as a critical reviewer of the efforts made by fellow workers. Nonetheless, those of us who are familiar with his outlooks know that his approach should not be taken personally. His observations and comments should be considered as advice from a tour-guide guiding the path he has traveled many times successfully to reaching the destination full of obstacles, failures and distractions as it is in one's career and personal life. In this time, when taxonomic studies have become endangered, facing threats from commercialization of education, the Taxonomists should learn from Prof. Nurul Islam's life, practice the learning and convey it to the generations to come. In this way we can hope for the revitalization of original taxonomic work in Bangladesh, a land full of opportunities to conduct systematic, biodiversity and conservation studies.

Prof. Nurul Islam has left his wife, a daughter, a son, two grandchildren, other relatives, numerous students, colleagues and admirers to mourn his death. May Allah grant him eternal peace.

- Haseeb Md. Irfanullah 